\title{
LEDER: BREDDE OG NATUR
}

Velger menigheter ut bibelstoff slik at barn og ungdom får et mangfoldig tilfang av fortellinger å speile seg i og reflektere over? Hvordan responderer et bredt sammensatt konfirmantkull på konfirmasjonsundervisning? Dekker eksisterende forskning på religion og livssyn i norsk barnehage feltet bredt nok? Det kan du lese om i dette nummeret av Prismet. I tillegg er det presentasjoner av det religionspedagogiske eller KRLE-faglige bidraget til to nyslåtte pensjonister, samt anmeldelse av bøker som viser bredde i ungdoms religion og skal gi framtidige lærere kunnskaper til å møte bredden av norske skoleelever.

Dette nummeret rommer også en artikkel med tittel «Friluftsliv, religion og stillhet». Her skriver Ola Hellenes om undervisning der folkehøgskoleelever både praktiserer friluftsliv og stillhet ute i naturen, og får møte keltisk spiritualitet. En av teoretikerne Hellenes st $ø$ tter seg på holder fram at mennesket i dag, i vår globaliserte og urbaniserte verden, er mer fremmedgjort fra naturen enn tidligere. Vi føler oss mindre som del av den naturen vi er så avhengig av og har lite kontakt med naturens rytme. Denne fremmedgjøringen påvirker holdninger og engasjement. Barn og unge trenger dermed ikke bare teoretisk kunnskap om natur og miljø, men naturmøter der naturen er i sentrum. Da kan opplevelsen av naturens egenverdi påvirke holdningene til naturen og engasjementet og viljen til å gjøre det som trengs for å ta vare på den.

Høstens nye rapport fra FNs klimapanel levner liten tvil om at det haster med å endre vaner og systemer. Hvor finner en motivasjon til dette? Det er svært langt fra entydig at religion styrker et miljøengasjement. Tvert om vil noen kunne uttrykke at så lenge en forventer en nyskapt jord er det ikke så farlig hvordan vi behandler den vi har. Men mange og dels toneangivende stemmer holder fram at tro og miljøengasjement går sammen og bør gå sammen; mennesket må bidra til å gjøre godt for alt det skapte og alle de skapte. Og det skjer mye 
på dette området nå, fra uttalelser fra paven til konferanser, utgivelser, ressurser, nettverksarbeid, medieoppslag og «miljømisjonering» i det små.

Om fremmedgjøring fra naturen er en del av grunnlaget for at vi turer fram slik vi gjør, kan praksiser som den Hellenes presenterer være viktig. Før sommeren kom også et nytt ressurshefte til trosopplæring kalt «Jordvenn». Det gir forslag til praksiser der vekten er på både natur og tro og sammenhengen mellom dem, blant annet påvirket av samisk tradisjon. Undertegnede har noen bånd til opphavspersonene bak dette heftet (det er utgitt av IKO) og skal ikke drive skjult reklame for det, men mottakelsen har tydet på at det å kunne inkludere naturerfaringer og $\emptyset$ koteologi i trosopplæringen er etterspurt. Norske trosopplæringsansatte virker å være blant dem som ser en sammenheng mellom tro og miljøengasjement, og ser at religionspedagogisk praksis ikke er uviktig i møte med klima- og miljøutfordringer.

Også i skolen ser vi konturene av en fornyet betoning av miljø og natur gjennom det nye tverrfaglige emnet «bærekraftig utvikling». I skissene til ny læreplan i KRLE er etisk refleksjon omkring menneskets forhold til naturen, om levesett, ressursbruk og klodens fremtid å finne i flere foreslåtte kompetansemål. I en læreplanfornyelse der en sentral oppgave har vært å gi mindre stofftrengsel i faget, anses spørsmål knyttet til natur, klima og miljø som så sentrale at de får mer plass.

Gunnfrid Ljones Øierud 